\title{
ANALISIS PERBANDINGAN METODE SAW DAN WP PADA SISTEM PENDUKUNG KEPUTUSAN PEMILIHAN WEDDING ORGANIZER DI SURABAYA
}

\author{
Prisa Marga Kusumantara $^{1}$, Mashita Kustyani' ${ }^{2}$, Tita Ayu $^{3}$ \\ Sistem Informasi, Fakultas Ilmu Komputer \\ Universitas Pembangunan Nasional "Veteran" Jawa Timur, Surabaya, Indonesia \\ e-mail : 1prisamarga.si@upnjatim.ac.id, ${ }^{2}$ mashitakyani@gmail.com, ${ }^{3}$ titarospriciliaa@gmail.com \\ Diterima: 25 April 2019. Disetujui : 11 Juni 2019. Dipublikasikan : 30 Juni 2019 \\ (C)2019 -TESJ Fakultas Teknik Universitas Maarif Hasyim Latif. Ini adalah artikel dengan \\ akses terbuka di bawah lisensi CC BY 4.0 (https://creativecommons.org/licenses/by/4.0/)
}

ABSTRAK

Saat ini banyak sekali jasa Wedding Organizer (WO) yang memudahkan calon pengantin dalam mempersiapkan pernikahan. Masing-masing jasa WO menawarkan banyak pilihan paket layanan pernikahan yang menarik, kompetitif dan spesifik. Di lain pihak, hal ini terkadang justru membuat calon pengantin menjadi sulit dalam menentukan pilihan WO. Untuk membantu dalam menentukan pengambilan keputusan tersebut, digunakan pendekatan Sistem Pendukung Keputusan (SPK). Kriteria yang digunakan meliputi : rating, tahun berdiri, harga, foto per roll, variasi menu makanan. Penelitian ini bertujuan untuk menganalisis hasil dari metode Simple Additive Weighting (SAW) dan Weighted Product (WP) sehingga dapat ditentukan metode mana yang lebih relevan untuk diimplementasikan pada kasus pemilihan WO di Surabaya. Berdasarkan data responden riil dari kuisioner beberapa pasangan calon pengantin, hasil pengukuran metode Hamming Distance menunjukkan selisih yang tidak terpaut jauh yaitu 78\% untuk metode SAW dan 80\% untuk metode WP. Meskipun secara umum kedua metode tersebut relatif sama-sama relevan, namun dalam beberapa kondisi khusus tertentu metode SAW dinilai relatif lebih relevan untuk diimplementasikan pada kasus ini dibandingkan dengan metode WP.

Kata kunci: pendukung keputusan, SAW, WP, Wedding Organizer

\section{PENDAHULUAN}

Pernikahan adalah semua impian calon pengantin. bahkan termasuk kategori ibadah bagi beberapa ajaran agama. banyak calon pengantin memimpikan pernikahan mereka berkesan, istimwa, sakral serta berjalan lancar dan sukses. Namun begitu, banyak sekali persiapan yang harus dipersiapkan, seperti misalnya : lokasi/gedung akad nikah, lokasi/gedung resepsi, katering hidangan, rias pengantin dan para anggota pengiring, dekorasi pengantin, paket foto pra/pasca wedding, bahkan sampai urusan sovenir. Segala persiapan tersebut diatas seringkali menjadi kekhawatiran tersendiri oleh pihak calon pengantin. Bahkan sangat menguras tenaga, pikiran, waktu dan biaya untuk memikirkan semua persiapan tersebut. Ditambah dengan minimnya pengalaman calon pengantin akan menambah sederetan permasalahan baru.

Saat ini jasa WO hadir dengan menawrkan banyak kemudahan. Semua persiapan mulai paket rias, paket catering, paket gedung dan hiburan, paket foto, sampai sovenir, semua sduah ditangani oleh pihak jasa WO. para calon pengantin tinggal menyampaikan konsep atau tema yang diinginkan maka pihak WO akan menangani semua. Saat ini, jasa WO di surabaya sudah cukup banyak. Mereka menawarkan keunggulan dan keunikan paket masing-masing. Misalnya, pada WO " $\mathrm{X}$ " memiliki keunggulan di masalah harga yg kompetitif, namun minim pengalaman. Dilain sisi, jasa WO "Y" memiliki banyak pengalaman namun harga nya relatif mahal. Sehingga, alih-alih calon pengantin ingin lepas dari kebingungan memilih jasa per paket nikah, sekarang para calon pengantin dihadapkan kepada masalah kebingungan memilih jasa WO mana yang sesuai dengan kebutuhan. Dari kondisi seperti ini kemudian dirasa perlu sebuah sistem berbasis IT yang dapat membantu calon pengantin untuk mendukung dalam mengambil keputusan untuk memilih WO mana yang sesuai kebutuhan.

$\begin{array}{ccc} & \text { Pendekatan Sistem Pendukung } & \text { Keputusan } \\ \text { (SPK) diharapkan mampu menjawab }\end{array}$ permasalahan para calon pengantin dalam memilih jasa WO. Beberpa penelitian SPK sebelumnya telah memperlihatkan bahwa kasus SPK pemilihan WO ini sudah banyak dibahas. Beberapa metode SPK juga sudah banyak diimplementasikan untuk kasus 
pemilihan WO ini mulai dari metode SAW, WP, AHP, Topsis, dst, seperti beberapa peneliti berikut ini :

a. Mifardi (2016) menggunakan metode SAW dengan menggunakan 6 kriteria : katering, dekorasi pelaminan, rias dan busana, hiburan dan dokumentasi, perlengkapan, harga.

b. Fatkhurrohmah (2016) menggunakan SAW dengan 5 kriteria : konsep, rias, fasilitas, pelayanan, harga.

c. Pramudita (2017) menggunakan metode SAW dengan 6 kriteria : katering, dokumentasi, dekorasi, rias, jumlah tamu dan harga paket.

d. Nofrisa, dkk (2018) menggunakan metode waspas dengan 4 kriteria : konsep, make up, pelayanan dan harga.

e. Destari (2018) menggunakan metode AHP dengan 5 kriteria : konsep, pelayanan, fasilitas, harga dan reputasi

f. Yuliani (2015) menggunakan AHP dengan 4 kriteria : budget, konsep, reputasi dan profesionalisme.

Analisis pembanding antar metode SPK yang memiliki kemiripan (karakter/langkah) juga sudah banyak dilakukan, seperti misalnya peneliti berikut ini :

a. Purnomo, dkk (2013) melakukan analisis pembanding antar metode AHP, TOPSIS dan AHPTOPSIS pada kasus seleksi penerimaan siswa dengan menggunakan 4 kriteria nilai, dimana setelah diukur dengan hamming distance dan euclidean distance menunjukkan bahwa metode yang direkomendasikan untuk kasus jenis tersebut adalah metode AHP.

b. Kungkung dan Kiswanto (2018) melakukan analisis pembanding antar metode SAW, WP, dan TOPSIS pada kasus seleksi penerimaan siswa dengan menggunakan 5 kriteria, dimana setelah diukur dengan hamming distance menunjukkan bahwa metode yang direkomendasikan untuk kasus jenis tersebut adalah metode SAW dan TOPSIS.

Berdasarkan keragaman metode yang dipakai para peneliti sebelumnya, maka penelitian kali ini bertujuan untuk membuat analisis perbandingan dari metode SAW dan WP dengan menggunakan 5 kriteria dan juga 5 kandidat alternatif. Pengukuran jumlah perbedaan dilakukan dengan teknik hamming distance (Siang, 2009) guna mengetahui metode manakah diantara SAW dan WP yang dinilai relatif sesuai/relevan untuk kasus pemilihan WO di Surabaya. Penentuan kedua metode ini bukan tanpa alasan, melainkan lebih karena SAW dan WP dinilai memiliki kemiripan karakter dan langkah dalam metodenya.

\section{METODE PENELITIAN}

Pada metode penelitian ini menggunakan tahapan :

1. Penentuan kriteria, bobot kriteria, dan cost/benefit analisis.

2. Penentuan alternatif.
3. Penentuan nilai per-kriteria per-alternatif.

4. Perhitungan rangking dengan metode SAW.

5. Perhitungan rangking dengan metode WP.

6. Perhitungan rangking dari quisioner responden riil.

7. Pengukuran distance rangking SAW dan WP berdasarkan dari rangking responden rill.

8. Pemilihan metode yang relevan.

\section{Sistem Pendukung Keputusan (SPK)}

Pada dasarnya SPK merupakan pengembangan lebih lanjut dari Sistem Informasi Manajemen terkomputerisasi yang dirancang sedemikian rupa sehingga bersifat interaktif dengan pemakainya. SPK ditujukan untuk keputusan keputusan yang memerlukan penilaian atau pada keputusan-keputusan yang sama sekali tidak dapat didukung oleh algoritma. Turban dkk. (2005).

\section{Simple Additive Weighting (SAW)}

SAW adalah metode yang umum dikenal sebagai metode penjumlahan terbobot. Inti dari metode ini adalah menghitung sigma (penjumlahan) dari rating kinerja terbobot per kriteria per alternatif (Turban dkk., 2005).

Menurut Kusumadewi, dkk (2006) Langkah penyelesaian SAW sebagai berikut :

1. Analisis masalah, tentukan tujuan, tentukan kriteria/prasyarat (Ci) dan bobot kriteria ternormasasi(W).

2. Tentukan alternatif(A) lengkap beserta value riilnya (rating kecocokan) pada setiap kriteria nya.

3. Susun matriks berdasarkan alternatif(A) dan kriteria(Ci).

4. Lakukan normalisasi matriks berdasarkan jenis atribut (cost/benefit) sehingga menjadi matriks ternormalisasi (R).

5. Menghitung nilai preferensi final per-alternatif (Vi) dengan cara sigma (penjumlahan) dari perkalian matriks R dengan bobot(W).

6. Nilai Vi terbesar adalah alternatif terbaik sebagai solusi.

$$
r_{i j}= \begin{cases}\frac{X_{i j}}{\operatorname{Max}_{i} X_{i j}} \rightarrow & \text { Jika } j \text { adalah attribute keuntungan } \\ \text { (benefit) }\end{cases}
$$

Formula (1) adalah untuk melakukan normalisasi pada rating kinerja, dimana :

$\mathrm{r}_{\mathrm{ij}} \quad$ : rating kinerja ternormalisasi

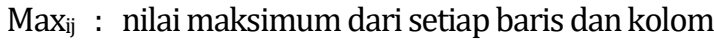

$\operatorname{Min}_{\mathrm{ij}}$ : nilai minimum dari setiap baris dan kolom

$\mathrm{x}_{\mathrm{ij}} \quad$ : baris dan kolom dari matriks

Dengan $r_{i j}$ adalah rating kinerja ternormalisasi dari alternatif $A_{i}$ pada atribut $C_{j ; i}=1,2, \ldots m$ dan ${ }_{j}=1,2, \ldots, n$.

Nilai preferensi untuk setiap alternatif $\left(\mathrm{V}_{\mathrm{i}}\right)$ diberikan formula (2). 


$$
\mathrm{V}_{\mathrm{i}}=\sum_{\mathrm{j}=1}^{\mathrm{n}} \mathrm{w}_{\mathrm{j}} \mathrm{r}_{\mathrm{ij}}
$$

\section{Weigthted Product (WP)}

Metode WP adalah metode penyelesaian dengan menggunakan perkalian untuk menghubungkan rating atribut, dimana rating harus dipangkatkan terlebih dahulu dengan bobot atribut yang bersangkutan. Proses ini sama halnya dengan proses normalisasi. (Turban dkk., 2005).

Menurut Kusumadewi, dkk (2006), untuk menormalisasikan nilai yang akan digunakan, menggunakan rumus (3).

$$
S_{i}=\prod_{j}^{n}=x_{i j^{w j}}
$$

Dengan $i=1,2, \ldots, \mathrm{m}$; dimana $\sum \mathrm{w}_{\mathrm{j}}=1$

$\mathrm{w}_{\mathrm{j}}$ adalah pangkat bernilai positif untuk atribut keuntungan, dan bernilai negatif untuk atribut biaya. Dan untuk mencari nilai akhir, menggunakan rumus (4).

$$
V_{i}=\frac{\prod_{j}^{n}=1 x_{i j^{w j}}}{\prod_{j}^{n}=1\left(x_{j^{*}}\right) w j}
$$

\section{HASIL DAN PEMBAHASAN}

\section{Penentuan kriteria, bobot dan cost/benefit analisis}

Pada studi kasus pemilihan WO di Surabaya didapatkan 5 (lima) kriteria umum, yaitu rating, tahun berdiri, harga, foto, dan variasi menu makanan. Maksud dari kriteria tersebut diberikan karena rating konsumen adalah salah satu kriteria yang mempengaruhi seseorang bersedia menggunakan jasa WO tersebut, rating dapat berupa review konsumen atau rating pada google. Kriteria Tahun berdiri dibutuhkan untuk mengetahui pengalaman WO tersebut. Kriteria harga dibutuhkan untuk menyesuaikan kemampuan konsumen sehingga konsumen dapat memilih harga sesuai budget. Kriteria foto dibutuhkan untuk mengetahui banyaknya roll foto yang akan didapatkan, dikarenakan roll foto ada didalam bagian Paket gedung. Kriteria variasi menu makanan dibutuhkan untuk mengetahui banyaknya variasi menu pada setiap WO, karena dengan harga yang sama belum tentu variasi makanan yang didapat juga sama. Maka jumlah variasi makanan juga dipertimbangkan dalam pemilihan WO. Berdasarkan data keriteria yang telah ditentukan maka dapat lima kriteria yang digunakan dalam proses pemilihan WO, antara lain yaitu rating (C1), tahun berdiri (C2), harga (C3), foto (C4) dan variasi menu makanan (C5).

Pada tabel 1 memperlihatkan bahwa khusus pada kriteria C2 dan C3 jenisnya adalah "cost", hal ini dikarenakan semakin tinggi nilainya maka semakin tidak diharapkan oleh pengguna. Semua kriteria tersebut juga diberi bobot dalam skala 1 sampai 5 dimana 1 = "sangat tidak penting", 2 = "tidak penting", 3 = "cukup penting", 4 = "penting", 5 = "sangat penting". Pemberian bobot per-kriteria tersebut kemudian dinormalisasi sehingga nilai $\sum$ bobot $=1$ atau $100 \%$. Perlu diketahui, bahwa pada pemberian bobot perkriteria ini adalah bersifat sangat relatif, tergantung dari

\begin{tabular}{|c|c|c|c|c|}
\hline Kode & Kriteria & Jenis & Bobot & $\begin{array}{c}\text { Bobot } \\
\text { normal }\end{array}$ \\
\hline $\mathrm{C} 1$ & Rating & Benefit & 3 & $20 \%$ \\
\hline $\mathrm{C} 2$ & Tahun Berdiri & Cost & 2 & $13,33 \%$ \\
\hline $\mathrm{C} 3$ & Harga & Cost & 4 & $26,67 \%$ \\
\hline C4 & Foto (roll) & Benefit & 3 & $20 \%$ \\
\hline \multirow[t]{2}{*}{ C5 } & $\begin{array}{l}\text { Variasi menu } \\
\text { makanan }\end{array}$ & Benefit & 3 & $20 \%$ \\
\hline & & & 15 & $100 \%$ \\
\hline
\end{tabular}
pengguna sistem pendukung keputusan itu nantinya.

Tabel 1. Tabel bobot dan tipe variabel

\section{Penentuan alternatif}

Tabel 2 menunjukkan ada 5 alternatif pilihan WO di Surabaya.

\begin{tabular}{cl}
\multicolumn{2}{c}{ Table 2. Tabel alternatif. } \\
\hline Kode & \multicolumn{1}{c}{ Alternatif } \\
\hline A1 & Bless Wedding \\
A2 & Rashdan Wedding \\
A3 & Juwita Wedding \\
A4 & Irani Service Wedding \\
A5 & Susy Profesional Wedding \\
\hline
\end{tabular}

\section{Penentuan nilai per-kriteria per-alternatif}

Tabel 3 menunjukkan tabel nilai riil, dimana pada tabel tersebut memperlihatkan data nilai riil dari setiap kriteria dari setiap alternatif WO yang ada di Surabaya.

Tabel 3. Tabel nilai per-kriteria per-alternatif.

\begin{tabular}{c|ccccc}
\hline Kode & C1 & C2 & C3 & C4 & C5 \\
\hline A1 & 4,5 & 1996 & $33,5 \mathrm{jt}$ & 3 & 9 \\
A2 & 4,5 & 1998 & $31.99 \mathrm{jt}$ & 4 & 7 \\
A3 & 4,4 & 2014 & $27,5 \mathrm{jt}$ & 3 & 8 \\
A4 & 4,4 & 2003 & $28 \mathrm{jt}$ & 3 & 8 \\
A5 & 4,3 & 2006 & $29 \mathrm{jt}$ & 4 & 6 \\
\hline
\end{tabular}

\section{Perhitungan rangking dengan metode SAW}

Tabel 4 menunjukkan perhitungan SAW dimana rating kinerja ternomalisasi per-Alternatif per-kriteria,

\begin{tabular}{|c|c|c|c|c|c|c|}
\hline & C1 & $\mathrm{C} 2$ & C3 & C4 & C5 & \multirow{4}{*}{$\begin{array}{c}\text { Total } \\
\text { Jumlah } \\
\text { (Vi) }\end{array}$} \\
\hline & ben & cost & cost & ben & ben & \\
\hline & $\mathrm{x} / \mathrm{max}$ & $\min / x$ & $\min / x$ & $\mathrm{x} / \mathrm{max}$ & $\mathrm{x} / \mathrm{max}$ & \\
\hline & ${ }^{*}$ bobot & * bobot & *bobot & *bobot & *bobot & \\
\hline \multirow[b]{2}{*}{ A1 } & $4,5 / 4,5$ & $1996 / 1996$ & $27,5 / 33,5$ & $3 / 4$ & $9 / 9$ & \multirow{2}{*}{0,9022} \\
\hline & ${ }^{*} 0,2$ & $* 0,1333$ & $* 0,2667$ & $* 0,2$ & $* 0,2$ & \\
\hline \multirow{2}{*}{ A2 } & $4,5 / 4,5$ & 1996/1998 & $27,5 / 31.99$ & $4 / 4$ & $7 / 9$ & \multirow{2}{*}{0,9179} \\
\hline & $* 0,2$ & ${ }^{*} 0,1333$ & ${ }^{*} 0,2667$ & $* 0,2$ & $* 0,2$ & \\
\hline \multirow{2}{*}{ A3 } & $4,4 / 4,5$ & $1996 / 2014$ & $27,5 / 27,5$ & $3 / 4$ & $8 / 9$ & \multirow{2}{*}{0,9221} \\
\hline & $* 0,2$ & $* 0,1333$ & $* 0,2667$ & $* 0,2$ & $* 0,2$ & \\
\hline \multirow{2}{*}{ A4 } & $4,4 / 4,5$ & $1996 / 2003$ & $27,5 / 28$ & $3 / 4$ & $8 / 9$ & \multirow{2}{*}{0,9181} \\
\hline & $* 0,2$ & ${ }^{*} 0,1333$ & ${ }^{*} 0,2667$ & 0,2 & $* 0,2$ & \\
\hline \multirow{2}{*}{ A5 } & $4,3 / 4,5$ & $1996 / 2006$ & $27,5 / 29$ & $4 / 4$ & $6 / 9$ & \multirow{2}{*}{0,9099} \\
\hline & $* 0,2$ & ${ }^{*} 0,1333$ & ${ }^{*} 0,2667$ & ${ }^{*} 0,2$ & $* 0,2$ & \\
\hline
\end{tabular}
yang sekaligus dikalikan dengan bobot per-kriteria.

Tabel 4. Tabel perhitungan SAW 
Nilai preferensi per-Alternatif (Va) sesuai rumus gambar 2 bisa diperoleh dari hasil penjumlahan semua rating kinerja ternomalisasi per-kriteria per-Alternatif yang nilainya seperti yang tertera pada tabel 4 . Hasil perolehan nilai preferensi per-Alternatif dengan metode SAW adalah : $V_{1}=0,9022, V_{2}=0,9179, \quad V_{3}=0,9221$, $V_{4}=0,9181, V_{5}=0,9099$.

\section{Perhitungan rangking dengan metode WP}

Tabel 5 menunjukkan perhitungan nilai preferensi per-Alternatif (Si) sesuai rumus pada gambar 3 dimana nilai per-kriteria dipangkatkan dengan bobot per-kriteria (tergantung syarat cost/benefit).

Tabel 5. Tabel perhitungan WP

\begin{tabular}{|c|c|c|c|c|c|c|}
\hline & C1 & C2 & C3 & C4 & C5 & Total \\
\hline & ben & cost & cost & ben & ben & Perkalian \\
\hline & $\mathrm{x}^{\mathrm{w}}$ & $\mathrm{x}^{-\mathrm{w}}$ & $x^{-w}$ & $\mathrm{x}^{\mathrm{w}}$ & $\mathrm{x}^{\mathrm{w}}$ & (Si) \\
\hline A1 & $4,5^{0,2}$ & $1996^{-0,13}$ & $33,5^{-0,27}$ & $3^{0,2}$ & 90,2 & 0,3717 \\
\hline A2 & $4,5^{0,2}$ & $1998^{-0,13}$ & $31.99^{-0,27}$ & $4^{0,2}$ & 70,2 & 0,3790 \\
\hline A3 & $4,4^{0,2}$ & $2014^{-0,13}$ & $27,5^{-0,27}$ & $3^{0,2}$ & $8^{0,2}$ & 0,3805 \\
\hline A4 & $4,4^{0,2}$ & $2003^{-0,13}$ & $28^{-0,27}$ & $3^{0,2}$ & $8^{0,2}$ & 0,3789 \\
\hline A5 & $4,3^{0,2}$ & $2006^{-0,13}$ & $29^{-0,27}$ & $4^{0,2}$ & $6^{0,2}$ & 0,3736 \\
\hline
\end{tabular}

Nilai preferensi per-Alternatif (Si) sesuai rumus gambar 3 bisa diperoleh dari hasil perkalian semua nilai per-kriteria per-Alternatif yang telah dipangkatkan positif atau negatif (tergantung cost/benefit) dari nilai yang tertera pada tabel 5. Hasil perolehan nilai preferensi per-Alternatif dengan metode WP adalah : $S_{1}=0,3717, S_{2}=0,3790, S_{3}=0,3805, S_{4}=0,3789$, dan $S_{5}=0,3736$.

Perhitungan rangking dari quisioner responden riil Tabel 6 menunjukkan perolehan rangking dari kuesioner kepada 10 responden pasangan calon pengantin yang diberikan data 5 WO di Surabaya. Sedangkan tabel 7 memperlihatkan perbedaan rangking WO yang diperoleh dari hasil perhitungan SAW dan WP pada tahap sebelumnya.

Tabel 6. Tabel rangking hasil responden riil

\begin{tabular}{c|cccccccccc}
\hline & R1 & R2 & R3 & R4 & R5 & R6 & R7 & R8 & R9 & R10 \\
\hline A1 & 1 & 5 & 4 & 1 & 3 & 3 & 3 & 4 & 4 & 1 \\
A2 & 2 & 4 & 3 & 2 & 4 & 2 & 4 & 3 & 5 & 2 \\
A3 & 4 & 1 & 2 & 3 & 1 & 1 & 2 & 2 & 3 & 3 \\
A4 & 3 & 2 & 1 & 4 & 2 & 5 & 5 & 5 & 2 & 4 \\
A5 & 5 & 3 & 5 & 5 & 5 & 4 & 1 & 1 & 1 & 5 \\
\hline
\end{tabular}

Tabel 7. Tabel perbedaan rangking hasil SAW dan WP

\begin{tabular}{c|cc}
\hline & SAW & WP \\
\hline A1 & 5 & 5 \\
A2 & 3 & 2 \\
A3 & 1 & 1 \\
A4 & 2 & 3 \\
A5 & 4 & 4 \\
\hline
\end{tabular}

Pengukuran distance rangking SAW dan WP berdasarkan dari rangking responden rill

Setelah mendapatkan rangking dari kedua metode dan rangking dari responden, kemudian dilakukan pengukuran dengan menggunakan metode hamming distance untuk mencari jumlah perbedaan rata-rata terkecil dari rangking hasil perhitungan metode SAW/WP terhadap rangking hasil responden riil. Hasil pengukuran hamming distance ditunjukkan pada tabel 8.

Tabel 8. Tabel Hamming Distance 10 sampel

\begin{tabular}{c|cccccccccc}
\hline & R1 & R2 & R3 & R4 & R5 & R6 & R7 & R8 & R9 & R10 \\
\hline SAW & 5 & 2 & 4 & 5 & 3 & 3 & 5 & 4 & 4 & 5 \\
WP & 3 & 3 & 5 & 4 & 4 & 2 & 5 & 5 & 5 & 4 \\
\hline
\end{tabular}

Berdasarkan tabel 8, secara kebetulan jumlah rata-rata hamming distance untuk SAW dan WP adalah sama-sama sebesar 4,0 satuan (dari 5 rangking) = 4,0/5 $=\mathbf{8 0} \%$.

Jika pada tabel 6 diasumsikan mendapat tambahan satu lagi responden sehingga total responden menjadi 11 dengan urutan rangking 1 sampai 5 secara berurutan sebagai berikut: $(\mathrm{R} 11)=\{\mathrm{A} 3, \mathrm{~A} 4, \mathrm{~A} 5, \mathrm{~A} 1, \mathrm{~A} 2\}$, maka hasil pengukuran ulang hamming distance pada tabel 8 akan berubah menjadi seperti tabel 9 .

Tabel 9. Tabel hamming distance 11 Sampel

\begin{tabular}{c|ccccccccccc}
\hline & R1 & R2 & R3 & R4 & R5 & R6 & R7 & R8 & R9 & R10 & R11 \\
\hline SAW & 5 & 2 & 4 & 5 & 3 & 3 & 5 & 4 & 4 & 5 & 3 \\
WP & 3 & 3 & 5 & 4 & 4 & 2 & 5 & 5 & 5 & 4 & 4 \\
\hline
\end{tabular}

Berdasarkan tabel 9, rata-rata hamming distance untuk SAW sebesar 43/11 satuan (dari 5 rangking) = $4,0 / 5=\mathbf{7 8} \%$. Sedangkan rata-rata hamming distance untuk WP sebesar 44/11 satuan (dari 5 rangking) = $4,0 / 5=80 \%$.

\section{Pemilihan metode yang relevan}

Berdasarkan hasil pengukuran hamming distance dimana pada metode SAW sebesar $78 \%$ dan pada metode WP sebesar 80\%, maka dapat diartikan bahwa pendekatan metode SAW relatif lebih relevan untuk dipilih sebagai rekomendasi untuk diimplementasikan pada kasus jenis ini dibandingkan dengan menggunakan metode WP.

\section{PENUTUP}

Setelah dilakukan perhitungan dengan pendekatan metode SAW dan WP, kemudian diukur dan diperbandingkan terhadap data riil kuesioner para responden dengan teknik hamming distance, pada percobaan pertama menunjukkan hasil yang sama antara SAW dan WP yaitu sebesar $80 \%$. Namun pada percobaan kedua dimana setelah ditambahkan data 1 responden baru, maka hasil pengukuran hamming distance menunjukkan angka yang sedikit berbeda yaitu 78\% untuk SAW dan $80 \%$ untuk WP.

Dari kedua kejadian tersebut diatas, dapat disimpulkan sekaligus dapat dimaknai bahwa secara umum kedua metode ini adalah relatif sama-sama relevan untuk diimplementasikan pada kasus jenis ini. Namun begitu, dalam beberapa kasus khusus tertentu, pendekatan metode SAW dinilai relative lebih relevan 
untuk diimplementasikan pada sistem pendukung keputusan kasus jenis ini dibandingkan dengan menggunakan metode WP.

Saran pengembangan untuk penelitian selanjutnya adalah penambahan jumlah sampel alternatif WO di Surabaya serta penambahan jumlah sampel para responden pemberi nilai rangking, guna menegaskan kembali bahwasanya metode SAW memang lebih relevan (dibandingkan WP) sebagai rekomendasi untuk diimplementasikan pada sistem pendukung keputusan studi kasus pemilihan WO di wilayah Surabaya ini. Meski begitu, tetap tidak menutup kemungkinan dilakukan analisis perbandingan pada metode-metode SPK yang lain guna menemukan nilai hamming distance yang lebih baik.

\section{DAFTAR PUSTAKA}

Destari, S., \& Simpony, B.K. (2018). Sistem Pendukung Keputusan Untuk Menentukan Wedding Organizer Menggunakan Metode AHP, Jurnal IJCIT (Indonesian Journal on Computer and Information Technology) -Universitas Bina Sarana Informatika Jakarta, 3(2), pp.197-207.

Fatkhurrohmah, F. (2016). Sistem Rekomendasi Pemilihan (Wedding Organizer) Dengan Metode Simple Additive Weighting (SAW) (skripsi). Teknik Informatika, UN PGRI Kediri.

Kungkung, A., \& Kiswanto, R.H. (2018). Analisa Perbandingan Metode SAW, WP dan TOPSIS Menggunakan Hamming Distance, Prosiding Konferensi Nasional Sistem Informasi (KNSI). STMIK Atma Luhur, Pangkalpinang.

Kusumadewi, S., Hartati, S., Harjoko, A., Wardoyo, R. (2006). Fuzzy Multi-Attribute Decision Making (Fuzzy MADM). Yogyakarta : Graha Ilmu.
Mifardi, M. (2016). Sistem Penunjang Keputusan Pemilihan Paket Pernikahan Menggunakan Metode Simple Additive Weighting (SAW). JIntech : Journal of Information and TechnologySTIKI Malang , 4(1), pp. 01-05.

Nofrisa, D., Umri, F., Nasution, J. (2018). Sistem Pendukung Keputusan Pemilihan Wedding Organizer Menggunakan Metode WASPAS. Prosiding : Seminar Nasional Sains \& Teknologi Informasi (SENSASI). Medan : Prodi Teknik Infomatika, STMIK Budi Darma, pp.416-420.

Pramudita I.,\& Nurgiyatna. (2017). Sistem Pendukung Keputusan Pemilihan Paket Pernikahan Berbasis Web dengan Menggunakan Metode SAW (Simple Additive Weighting) Studi Kasus Di Joglomas Solo (skripsi). Teknik Informatika, Universitas Muhammadiyah Surakarta.

Purnomo, E.N.S. (2013). Analisis Perbandingan Menggunakan Metode AHP, TOPSIS dan AHPTOPSIS Sistem Pendukung Keputusan Penerimaan Siswa Program Akselerasi. ITSMART: Jurnal Teknologi dan Informasi - Universitas 11 Maret, 2(1), pp.16-23.

Siang J.J., (2009). Matematika Diskrit dan Aplikasinya Pada Ilmu Komputer.

Turban, E., Aronson, J.E., \& Liang, T. (2005). Decision Support Systems and Intelligent Systems - 7th Edition. Prentice Hall.

Yuliani, I.D.A.E.,\& Kosasi, S. (2015). Sistem Pendukung Keputusan Pemilihan Wedding Organizer, Jurnal Eksplora Informatika - STMIK Pontianak, 5(1), pp. 23-32. 
PM Kusumantara, dkk / Teknika : Engineering and Sains Journal, Vol. 3, No.1, Juni 2019, 19-24

Halaman ini sengaja dikosongkan 